\title{
Strategic Communication to Socialize Smoke Free Area in Klungkung, Bali, Indonesia)
}

\author{
Adhianty Nurjanah ${ }^{1 *}$, Yeni Rosilawati ${ }^{2}$ \\ ${ }^{1,2}$ Communication Studies, Universitas Muhammadiyah Yogyakarta, Indonesia \\ *corresponding email: adhianty@umy.ac.id
}

\begin{abstract}
The Bali Provincial Government effectively applied local regulations (Perda) Number 1 of 2014 and Perbup Klungkung Number 1 of 2016 concerning Procedures for the Development and Supervision of KTR including encouraging the inclusion of the KTR in Perarem (customary rules) in each Customary Village. Klungkung Regency is the smallest regency in the province of Bali, Indonesia. The smoke free zone in Bali regulates that smokers don't smoke anywhere, therefore exposure to cigarette smoke does not affect vulnerable groups, namely children, adolescents and pregnant women. This study will evaluate the communication strategic to socialize Smoke Free Area in Klungkung Regency in Bali Province, Indonesia. The result found that the government made effective strategic communication through customary rules by Desa Adat. By way, it also prohibits cigarette advertising both in shops, shops and in other public places. Install anti-smoking billboards, form anti-smoking cadres and socialize the dangers of smoking in schools and communities
\end{abstract}

Keywords: Policy, Tobacco Prevention, Klungkung Bali Indonesia

\section{INTRODUCTION}

Various studies on the dangers of smoking are supported by the longer people smoke, the greater the risk they receive. This is because cigarettes contain active tobacco with nicotine contents. Nicotine is a very dangerous substance because it has addictive properties and more than 4000 substances that make potential health side effects and are risky in daily life, both consumed by suction as well as chewing. Countries with lower middle class smokers are still young. The rate of teenage smokers is increasing. Initiation is increasingly reduced to increase cigarette freedom and this is a major concern for developing regions such as Indonesia. Indonesia is the 4th most populous country in the world with a total population of 261.1 million people.

The prevalence of young smokers is higher and higher this will bring the issue that Indonesia is increasing the burden of premature morbidity and morality because of the higher consumption of tobacco or cigarettes among teenagers. The next few years successfully did not take steps to improve it will be even more premature. Culture in Indonesia is often offered to be special. Most of the regions still accept cigarettes which become social interaction, more among men. Although the initiation and predictor of smoking is done by teenagers in the west well but it is inversely proportional to the situation in Asia Pacific. The number of smokers is still increasing in developing countries. Who predicts $50 \%$ of men and $8 \%$ of women in developing countries have smoked and smokers. Men practice culture as a practice without limits.
While adult women with active smoker status are below $5 \%$. Nevertheless, the results of a survey conducted in the territory of Indonesia still show the number of smokers are high school children, and the results are varied. Even so there are still many different results on this method, and age groups as smokers.

The world trend is growing, spending a lifetime of consumption will increase data on the deaths of 250 million children and and young people. Those with high risk are in areas with LMIC. As a region with a high population density of 261.1 million, attracting cigarette manufacturers to increase their investment by selling their cigarettes in Indonesia.

The Bali Provincial Government effectively applied local regulations (Perda) Number 10 of 2014 concerning Smoke Free Area (Kawasan Tanpa Rokok) or called KTR since June 1, 2012. The KTR regulates that smokers do not smoke anywhere, therefore exposure to cigarette smoke does not affect vulnerable groups, namely children, adolescents and pregnant women. More broadly, this regulation is intended to protect the public from the dangers of exposure to cigarette smoke. In addition, the KTR Regional Regulation also aims to create a cleaner space and environment for the community and prevent the emergence of novice smokers. In its implementation, KTR is effectively implemented applies to areas of learning and teaching, places of worship, public transportation, children's playgrounds, health services, workplaces, sports locations, city parks and other locations. 
Smoking cigarettes has become widely acknowledged as a behavior that entails many serious health risks. Numerous by laws, retail protocols, and public health initiatives have attempted to prevent the initiation of smoking in adolescents specifically. According to Statistics Canada, the rate of smoking among Canadian adolescents has shown greater reduction than that of any other age group between 2001 and 2011 (Janz, 2012). Smoking rates among men aged 18-19 have declined by $13.4 \%$, while males aged $15-17$ have demonstrated a decline in smoking by $9.2 \%$. Female statistics depict a similar trend, with ages 18-19 and 15-17 to declining by $15.7 \%$ and $13.6 \%$, respectively. These statistics emphasize the progress in adolescent smoking rates; however, cigarette use remains a critical issue because in 2011, the overall smoking rate in adolescents was still as high as $20 \%$ (Janz, 2012).

Janz (2012) reported that adolescents aged 15-17 were three times more likely to smoke if someone in their household was a regular smoker. Although these statistics support the social learning theory, it is not clear if this finding is due to parental influence specifically, as it could be related to the smoking habits of a sibling or extended family member living in the household. Parental smoking behavior has also been found to influence adolescent smoking transitions (for example, an irregular smoker becoming a regular smoker). Bricker and colleagues (2006) surveyed 5520 American families and found that parental smoking is associated with a high probability of adolescent experimentation with smoking, as well as transitioning from monthly smoking to daily smoking. While these studies present a strong case for the negative impact of parental smoking across the span of adolescence, other research supports differing degrees of parental influence throughout adolescence.

\section{COMMUNICATION STRATEGY}

Middleton in Hafied Cangara (2013: 61) stated that the communication strategy is the best combination of all communication elements ranging from the communicators, messages, channels (media), the recipients, to the influence (effects) designed to achieve optimal goals. Communication strategy is the creation of communication programs designed to influence and support voluntary change in target groups and relevant stakeholders in order to achieve development goals (Manfred Oepen, 2003).

Strategy in communication studies according to Rustan and Hakki (2017: 120) covers communication skills in using effective communication resources to achieve the goals and objectives of any communication activity. Rogers in Cangara (2013: 61) defines the notion of a communication strategy as a plan who's designed to change human behavior on a larger scale through the transfer of new ideas. A communication strategy should include everything that is needed to know how to communicate with target audiences.

A communication strategy is a combination of communication planning with communication management to achieve predetermined goals. The communication strategy must be able to show how the operation should be practically done, in the sense that the approach can be different at any time depending on the situation and conditions (Kalianda, 2018). The communication strategy defines the target audience, the various actions to be taken, stated how the target audience will benefit from its point of view, and how the larger target audience can be reached more effectively. Meanwhile, Mohr and Nevin (in Kulvisaechana, 2001: 17-18) defines the communication strategy as the use of a combination of communication facets which includes communication frequency, communication formality, communication content, and communication channels.

In implementing a communication strategy, appropriate tactics or methods are needed. Tactics and strategy are closely related. If a strategy that has been drawn up with care is the right strategy to use, then tactics can be changed before strategy. According to Mintzberg and Quinn in Ruslan (2002: 29), a communication strategy is a planned strategy that is able to compile and manage organizational resources with unique results and is able to survive for a long time based on internal abilities and weaknesses, anticipating the actions from rivals and opponents.

Furthermore, Mintzberg and Quinn in Ruslan (2002: 36) argue that strategy is related to 5 things, which are: (1) Strategy as a plan: a strategy is a plan that guides the organization to achieve the goals and objectives that have been set; (2) Strategy as a pattern: a strategy is an organizational way or a consistent pattern of action carried out by the organization over a long period of time; (3) Strategy as a position: strategy is an organization's way of putting something in the right place; (4) Strategy as a perspective: strategy is an organization's perspective in carrying out various policies. This perspective is related to the vision and mission of the organizational culture; (5) Strategy as a play: specific ways or maneuvers carried out by the organization to defeat rivals or competitors.

The communication strategy is a way to provide any information to audiences and determine how to communicate that information in order to be accepted by the communicant in accordance with the wishes and goals of the communicator in joint decisions.

\section{METHODS}

Data collection was done using face-to-face interviews. The data base for this paper came from face-to-face interviews with local government, local community leaders and members and NGO members. The qualitative software QSR-NVivo 11 was used to clean the data, code and analyze the data sets. In qualitative research, computer packages such as QSR-NVivo 11, increase analysis transparency, accuracy, efficiency, rigour and trustworthiness. As part of the analysis process, NVivo 'word frequency queries' were run to identify words and word groups (e.g. stem words, synonyms) that occurred most often, as well as the relative and absolute 
frequency of word/word groups within the data set. To ensure the comprehensiveness of data in terms of data coverage, "text search queries' were used to look for (1) specific themes and subthemes; (2) words with a shared stem and (3) words with related meanings. Apart from that, all the documents and reports regarding tobacco prevention programs and other initiatives were analyzed thoroughly.

\section{RESULT AND DISCUSSION}

Klungkung Regency is the smallest regency in the province of Bali, Indonesia. The capital city is in Semarapura. Klungkung is bordered by Bangli Regency in the north, Karangasem Regency in the east, Gianyar Regency in the west and with the Indian Ocean in the south. One third of the Klungkung Regency area $\left(112.16 \mathrm{~km}^{2}\right)$ is located between the island of Bali and two thirds $\left(202.84 \mathrm{~km}^{2}\right)$ again are islands, namely Nusa Penida, Nusa Lembongan and Nusa Ceningan. Klungkung Regency consists of 4 districts, 6 villages, and 53 villages. In 2017 , the population reached 215,852 people with an area of $315.00 \mathrm{~km}^{2}$ and a population distribution of 685 people $/ \mathrm{km}^{2}$.

The implementation of the tobacco prevention to smoke free activity area in Klungkung, Bali, Indonesia is as follows:

\subsection{Socialization to schools}

The socialization was given by a team from the District Klungkung's Health Office and Klungkung's Health Centre II to 54 students from SMA Negeri 2 Semarapura 2 who are members of the Youth Health Cadre which is a combination of extra-curricular Youth Red Cross, Student Group Concerned with Aids and Drugs, and Youth Counselling and Information Centre. Clean and Healthy Living Behaviour is a habit that becomes a behavior in maintaining a clean and healthy life, as the saying goes, "it costs money to stay healthy, but it's even more expensive to get sick." Students are expected to be able to maintain their health by implementing clean and healthy living habits in their daily lives. Clean and Healthy Living Behaviour includes doing physical activity at least 30 minutes per day, washing hands with soap as often as possible, especially before and after eating, after urinating and defecating, disposing of garbage in its place, maintaining environmental cleanliness, and consuming healthy and nutritious food and drinks.

In relation to No Smoking Areas, the Klungkung District Government has issued regional regulation No. 1/2014 on Kawasan Tanpa Rokok or No Smoking Areas. In the regulation, it is stated that a Kawasan Tanpa Rokok (KTR) or No Smoking Area, is a room or area that is declared prohibited for smoking activities or activities to produce, sell, advertise, and/or promote tobacco products. No smoking area includes health service facilities, places for teaching and learning, places for children to play, places of worship, public transportation, workplaces, public places, and other designated places. Because schools are one of the NonSmoking Areas, students, teachers, employees, and school members others are prohibited from consuming tobacco products or cigarettes.

Advertisements, billboards, and even cigarette stickers prohibited to be posted in the Klungkung area. In line with the existence of Regional Regulation (Perda) number 3 of 2014 concerning No-Smoking Areas, the Depok City Civil Service Police Unit (Satpol PP) has controlled banners and cigarette billboards installed in public spaces.

\subsection{Making Local Regulations and Regulations}

No Smoking Zone (KTR) rules are applied not only in public areas and public services. The strict rules of the Klungkung Regional Government are applied with the prohibition of cigarette banners and even the installation of cigarette stickers. The local government of Klungkung Government also applied strict rules to cigarette banners or billboards on the road. Networked shops are also required not to display cigarettes at the front of the outlets. This is because it will lead to the desire of adolescents to smoke cigarettes.

In addition, the implementation of local government policies also issued regulations by making a legal umbrella in the form of Regional Regulation (Perda) Number 1 of 2014 concerning Non-Smoking Areas (KTR) and Regents Regulations (Perbup) Number 1 of 2016 concerning Procedures for Development and Supervision of KTR. Another step in controlling tobacco products is the commitment to curb cigarette advertisements in Klungkung Regency, through Perbup Number 5 of 2016 concerning Implementation of Billboard Installation. Quoted from Balitribune, the Regent of Klungkung is committed to controlling tobacco products which have been followed up by conducting socialization, implementation, supervision and enforcement of the applicable regulations as concrete steps that must be carried out continuously.

With the adoption of this regulation, the level of compliance in each region has increased, reaching 50 percent and above. One of them is the office environment reaches 75 percent, in addition to the level of compliance in health facilities, educational facilities and children's play facilities that have reached 100 percent.

\subsection{Making Perarem (traditional rules) about No Smoking Areas in each Customary Village.}

The Regent of Klungkung, Suwirta, stated that the control of tobacco products cannot only be carried out by the government alone. But community support and commitment is also needed. One way to do this is by entering into Perarem (adat rules) in each Pakraman village in Klungkung. Although it is difficult to maintain these regulations, now Klungkung Regency is the only region with 100 percent of the villages having no-smoking area regulations.

Even though all villages in Klungkung Regency already have customary regulations, the local government said that it was still necessary to conduct socialization with community 
leaders and traditional adat leaders to maintain the nonsmoking area regulation in Klungkung Bali.

The policy approach to support the KTR program is a free student transportation program which is a means of tobacco control campaigns, violations of cigarette advertising outside the home, as well as a ban on advertising, promotion and sponsorship of cigarettes in the right places)

\section{CONCLUSION}

The Bali Provincial Government effectively applied local regulations (Perda) Number 10 of 2011 concerning Smoke Free Area (Kawasan Tanpa Rokok) The KTR regulates that smokers do not smoke anywhere, therefore exposure to cigarette smoke does not affect vulnerable groups, namely children, adolescents and pregnant women. The policy is supported by the Law of number 36 of 2009 in realizing public health welfare. The Application of No-Smoking Areas (KTR) in Klungkung Regency has been implemented since 2014. Since the enactment of PERDA No. 1 of 2014 on NonSmoking Areas (KTR).

The Policy of against tobacco in Klungkung is developed to protect nonsmokers from the harmful effects of secondhand smoke, contribute to the demoralization of smoking, and decrease consumption. Strategic communication approaches were developed in response to limited reach of individual and small group programs, low penetration of programs to some segments of populations; and the desire to develop program to achieve change in populations. The government also involving other stakeholders such as schools, community organizations to cooperate and collaborate in the program. The usage of channel or medium and by involving mother and family as well as community support to educate the danger of tobacco both are effective.

This research focuses on the implementation of the policy applied to the government of Klungkung Regency, Bali Province of Indonesia to make Klungkung Regency a nonsmoking area.The policy is the local regulations (Perda) Number 10 of 2011 concerning Smoke Free Area. Finally, the policy is the local regulations (Perda) Number 10 of 2014 concerning Smoke Free Area by Desa Adat. By way, it prohibits cigarette advertisements both in shops, shops and in other public places. Install anti-smoking billboards, form antismoking cadres and socialize the dangers of smoking in schools and the student transport fleet for free.

\section{REFERENCES}

Anderson, A. D. (2018). Quitting Together: Formative Research to Develop a Social Marketing Plan for Smoking Cessation Among Women in a Residential Treatment Facility for Substance Abuse Recovery. University of Kentucky.

Andreasen,R. (1995). Marketing Social Change Changing Behavior to Promote Health, Development, and the Environment. San Francisco: Jossey Bass
Antaranews. (2019). Kabupaten Klungkung Terapkan Perda KTR Sebagai Aturan Adat. Retrieved from https://www.antaranews.com/berita/1081122/kabupatenklungkung-terapkan-perda-ktr-sebagai-aturan-adat

Balitribune. 2020. Klungkung Jadi Pioner Percontohan Daerah KTR di Asia Pasifik. Retrieved from https://balitribune.co.id/content/klungkung-jadi-pionerpercontohan-daerah-ktr-di-asia-pasifik

Bandura, A., \& Davidson Films Inc. (2003). Bandura's social cognitive theory: An introduction Retrieved from http://ediv.alexanderstreet.com.proxy.bib.uottawa.ca/View/16 4109

Centers for Disease Control and Prevention, U.S. Department of Health and Human Services and National Center for Chronic Disease Prevention and Health Promotion. (2003). Designing and Implementing an Effective Tobacco Counter-Marketing Campaign. Available at: http://www.cdc.gov/tobacco/stateandcommunity/counter_mar keting/manual/.

Freeman, B. (2012). New Media And Tobacco Control. doi: 10.1136/tobaccocontrol-2011-050193.

Gallopel-Morvan, K. et al. (2011). The Use Of Visual Warnings In Social Marketing: The Case Of Tobacco. Journal Of Business Research. Elsevier B. Vol. 64(1), p. 7-11. Doi: 10.1016/j.jbusres.2009.09.012.

Griffin KW, Botvin GJ, Doyle MM, Diaz T, Epstein JA. (1999). A Six-Year Follow-Up Study Of Determinants Of Heavy Cigarette Smoking Among High-School Seniors. Journal Behavior Medical Vol. 22, P. 271-84.

Janz, T. (2012, June). Health at a glance: Current smoking trends. Retrieved from http://www.statcan.gc.ca/pub/82-624x/2012001/article/11676-eng.htm

Kotler, P. \& Gertner, D. (2002). Theoretical papers. Country as brand, product, and beyound: A place marketing and brand management perspective. Special Issue Brand Management, Vol. 9 (4), p. 5.

Kotler, Philip dan Zaltman, G. (1971). Social Marketing; An Approach To Planned Social Change. Journal of Marketing. Vol. 35 pp 3-12.

L Hayward, I Lambraki, J. G. (2012). Social Marketing to Influence Young Adults. Tobacco Behaviour.

McLean, Geoffrey. (2010). Social Marketing. SBS HDR Student Conference. 16. http://ro.uow.edu.au/sbshdr/2010/papers

World Health Organization. (2015). WHO Report On The Global Tobaco Epidemic, 2015: Raising Tax On Tobacco. Geneva: World Health Organization 